\title{
A PESTE NA GÁLIA dO SÉCULO VI
}

\section{The Plague in 6th century Gaul}

\begin{abstract}
Prof. Dr. Edmar Checon de Freitas Professor de História Medieval do Departamento de História e do Programa de Pós-Graduação em História da UFF Pesquisador do Scriptorium - Laboratório de Estudos Medievais e Ibéricos e do Agios - Grupo de Estudos sobre Hagiografia e Santidade (UFF) ORCID: https://orcid.org/0000-0003-0165-317X e-mail: edmarcfreitas@gmail.com
\end{abstract}

Recebido em: 30/10/2020 Aprovado em: 05/02/2021

\begin{abstract}
Resumo: O artigo discute a pandemia de peste bubônica ocorrida no século VI, conhecida como Peste Justiniana. De modo especial são analisadas as referências à peste e a outras epidemias nos escritos de Gregório de Tours (538-594), buscando-se apreender de que forma por ele foram percebidas e como influenciaram suas representações do seu tempo e do seu mundo.
\end{abstract}

Palavras-chave: História da Alta Idade Média - História das epidemias - Peste na Idade Média

Abstract: The article discusses the bubonic plague pandemic that occurred in the 6th century, known as the Justiniana plague. In particular, here are analyzed the references to the plague and other epidemics in the writings of Gregório de Tours (538-594), seeking to apprehend how they were perceived and how they impact his representations of his own time and world.

Keywords: History of Early Middle Ages - History of epidemics - Plague in the Middle Ages 


\section{Introdução}

As epidemias de peste figuram como um dos principais elementos constitutivos do imaginário contemporâneo acerca da Idade Média. Cadáveres espalhados pelas ruas ou transportados em carretas para valas comuns, pessoas fugindo em pânico, médicos escondidos por detrás de máscaras odoríferas, tudo isso corresponde a uma tradição iconográfica, literária e mesmo cinematográfica que remete ao pesadelo da Peste Negra (1348) e das sucessivas aparições dessa doença na Europa até o século XVIII. Essa não foi, entretanto, a primeira manifestação em grande escala da peste. Registram-se efetivamente três pandemias associadas a essa doença: a primeira, da qual aqui nos ocuparemos, assolou o mundo mediterrâneo em sucessivas ondas entre c.540 e c.750; a segunda correspondeu justamente ao longo ciclo de pestes iniciado no século XIV mencionado acima; a terceira acometeu o continente asiático entre o final do século XIX e meados do século XX.

A peste dos séculos VI-VIII é tradicionalmente conhecida como "Peste Justiniana", visto seu aparecimento e ação mais virulenta terem ocorrido nos tempos do longo e marcante reinado em Constantinopla do imperador Justiniano (527-565). Comparativamente à segunda e terceira pandemias a Peste Justiniana é escassamente documentada, destacando-se ainda hoje nas tentativas de reconstituição do seu percurso o peso da documentação textual, sobretudo narrativa. Mas ao longo do século XX as pesquisas relacionadas à terceira pandemia de peste, sobretudo no campo da epidemiologia, ampliaram a base de conhecimento acerca da doença e permitiram uma melhor compreensão também das ocorrência medievais da mesma. Isso somado ao grande desenvolvimento das técnicas de pesquisa nos campos da arqueologia, da microbiologia, da genética, dentre outros, estimularam nas últimas décadas a revisitação das temáticas associadas às manifestações da peste na Idade Média, não apenas no plano da ciência médica, mas também no que se refere às dinâmicas social, econômica, política e cultural.

Nesse particular a Peste Justiniana tem sido objeto de estudos e debates sobretudo centrados na relação entre a mesma e os processos de desgregação, crise ou mesmo colapso do Império Romano, com destaque para a exploração da documentação relacionada à porção oriental do mesmo. No presente trabalho optamos por caminho 
diverso. Concentraremos nossa atenção no caso da Gália, região ocidental profundamente associada às transformações do mundo romano e bastante castigada pela peste nos séculos VI-VII e para a qual possuímos o testemunho privilegiado do bispo Gregório de Tours (538-594), que não só escreveu sobre ela mas que o fez sob sua influência. Antes, porém, faremos uma breve caracterização geral da Peste Justiniana e dos debates que tem suscitado na comunidade acadêmica.

\section{A Peste Justiniana}

O interesse renovado no estudo da peste na Alta Idade Média é evidenciado pela publicação na revista Annales de um artigo assinado por Jacques Le Goff e Jean-Noël Biraben (1969), o qual veio a se constituir num verdadeiro marco historiográfico nessa temática. $\mathrm{O}$ trabalho reuniu as conclusões das investigações conduzidas independentemente por ambos na décadas que se findava. ${ }^{1}$ No caso de Le Goff tratavase do resultado dos estudos realizados no âmbito de um seminário da VI Seção da École Pratique des Hautes Études, que tinha por tema geral e título "Histoire et sociologie de l'Occident Médiéval" (Schmitt, 1998: 24). Quanto a Biraben, cujas publicações sobre o tema remontam ao fim dos anos 1950, o material publicado em 1969 remetia às suas pesquisas sobre a peste na história das populações no Institut National d'Études Démographiques (Biraben; Le Goff, 1969: 1484, n.1). ${ }^{2}$

O artigo de Biraben e Le Goff apresenta inicialmente um estudo da sintomatologia e da epidemiologia da infecção pelo bacilo Yersinia pestis, tomando por base as pesquisas médicas desenvolvidas, sobretudo, na esteira da pandemia asiática. Além da descrição dos sintomas clássicos - febres, bubões, pústulas, hemorragias e alucinações - merece destaque a descrição detalhada do mecanismo de infecção e propagação da doença. Aparece aí em relevo o modelo convencional rato/pulga, segundo o qual esses roedores funcionariam como hospedeiros e grandes reservatórios de bacilos transmitidos aos seres humanos pela puga Xenopsylla chéopis que, ao contrário das demais espécies desse inseto, parasitam tanto os ratos quanto os homens. A apresentação de Biraben e Le Goff registra ainda a possibilidade de transmissão oral (peste pulmonar) e procura matizar a vinculação da propagação da doença à presença abundante do rato preto (Ratus ratus), registrando a possível transmissão sustentada do 
bacilo entre diferentes espécies de roedores selvagens (Biraben; Le Goff, 1969: 14851490).

Em linhas gerais a caracterização da Peste Justiniana por Le Goff e Biraben segue o registro das mesmas nas fontes cronísticas do século VI, com destaque para Procópio († c.560) e Evágrio Escolástico († 590), no Oriente, e Gregório de Tours e Paulo Diácono ( † 766), para o Ocidente. A primeira irrupção da epidemia teria se dado em 541 no porto egípcio de Pelusa, no Mediterrâneo, segundo Procópio (Hist. Guerras, II,22) ou na Etiópia, de acordo com Evágrio (História Eclesiástica. IV,29). Daí teria se espalhado pelo Egito, Síria e Palestina ao longo do ano seguinte, vindo a atingir Constantinopla na primavera de 542. No mesmo ano o flagelo ainda atingiria o Ilírico, as costas africanas do Mediterrâneo ocidental e a Espanha, chegando em 543 à Itália e à Gália. A partir de então a peste viria a se deslocar em sucessivas ondas ao longo das regiões mediterrâneas, bem como avançaria no continente europeu em direção ao Norte. Biraben e Le Goff registram um total de quinze vagas de peste entre 541 e 767, separadas entre si por períodos que variam, na maior parte dos casos, de dez a quinze anos (Biraben; Le Goff, 1969: 1492-1493).

A identificação da epidemia descrita pelos cronistas do século VI com a peste bubônica é feita por Le Goff e Biraben mediante a comparação dos sintomas registrados nas fontes da época com aqueles documentados para a segunda e terceiras pandemias. Mais especificamente são comparadas as referências ao aparecimento dos bubões nas obras de Procópio, Gregório de Tours e Paulo Diácono. Em seguida os autores passam a considerar a percepção e as reações à peste por parte das populações afetadas, com destaque para as explicações que faziam apelo ao castigo divino e o correlato enfrentamento no plano espiritual, recorrendo-se às preces, vigílias, jejuns e à intervenção do santos (Biraben; Le Goff, 1969: 1498).

Na parte final desse artigo Biraben e Le Goff tecem algumas considerações acerca da relação entre a propagação da peste e as transformações sociais, econômicas e políticas que marcaram a passagem da Antiguidade à Idade Média. A ideia central, lançada como hipótese especulativa, coloca em paralelo os transtornos causados pela peste nas regiões mediterrâneas e a relativamente mais fraca incidência da mesma mais ao norte, o que poderia explicar o deslocamento político-econômico do Sul para o Norte 
na Alta Idade Média. No limite a peste explicaria Maomé e Carlos Magno (Biraben; Le Goff, 1969: 1498-1508).

A caracterização geral da peste dos séculos VI-VIII por Biraben e Le Goff permanece válida ainda hoje, ao menos como uma boa descrição aproximativa do fenômeno. A esperança que os autores manifestam numa das notas do artigo quanto ao desenvolvimento de pesquisas multidisciplinares que viessem a ampliar o conhecimento acerca dessa pandemia também vem se concretizando nas últimas décadas (Biraben; Le Goff, 1969: 1484, n.2). Nos primeiros anos do século XXI a presença de DNA do bacilo Yersinia pestis foi atestada em restos humanos datados do século VI, um forte indício de que a doença de que falam as fontes da época era mesmo a peste bubônica (Wiechmann; Grupe, 2005; Drancourt et al., 2007). Pesquisas mais recentes vêm confirmando essa identificação mediante o sequenciamento genômico completo do bacilo Yersina pestis (Harbeck et al., 2013; Wagner et al., 2014). ${ }^{3}$ Foram identificadas as linhagens associadas às diferentes pandemias de peste ( Harbeck et al., 2013: 324), bem como estabelecida a filiação genética do $Y$. pestis com relação ao $Y$. psedutuberculosis, outro bacilo que infecta roedores e seres humanos, porém com efeitos bem mais brandos nesses últimos ( Wagner et al., 2014; Harper, 2017: 206-209). ${ }^{4}$

No que diz respeito aos impactos da peste nas transformações do mundo romano ao final da Antiguidade os debates têm sido caracterizados por uma oposição entre os que reservam à mesma um lugar central nesse processo e os que minimizam tal influência. Na esteira das proposições de Biraben e Le Goff trabalhos como os de Allen (1979), Liebeschuetz (2001), Sarris (2002), Stathakopoulos (2004; 2016), Little (2006), Rosen (2007), Meyer (2016) e Harper (2017) têm reforçado a conexão entre a peste e a aceleração dessas transformações. Numa das abordagens mais recentes, Kyle Harper associa o fim do Império Romano à propagação de epidemias, especialmente a peste, a seu ver favorecidas pelas condições climáticas da época e pela circulação de pessoas e mercadorias no Mediterrâneo (Harper, 2017).

Uma posição oposta manifesta-se principalmente nas contribuições de Durliat (1989) e nos trabalhos conjuntos de Eisemberg e Mordechai (2019). De acordo com essa segunda perspectiva o alcance e as consequências da peste dos séculos VI-VIII teriam sido superestimados em boa parte das pesquisas anteriores, compondo uma visão catastrofista construída com base nos exageros retóricos dos cronistas medievais. Desse 
modo, tanto os níveis de mortalidade quanto as consequências econômicas, políticas e sociais seriam menos drásticos do que supunham os autores anteriormente citados. Mordechai e Eisemberg (2019: 48) admitem que em certos locais o número de mortos possa ter sido elevado, causando forte impressão nos contemporâneos, mas os efeitos globais e de longo prazo seriam pequenos.

Essa perspectiva revisionista converge com as proposições das importantes sínteses sobre o período elaboradas por Wickham (2005; 2009) e Ward-Perkins (2005). Para o primeiro a peste teria sido um evento marginal em termos demográficos, em que pese seu impacto a nível local. Isso porque o decréscimo populacional associado à Alta Idade Média já teria se iniciado no século $\mathrm{V}$, antes portanto, da irrupção da pandemia de peste bubônica (Wickham, 2005: 548-549). De acordo com Ward-Perkins (2005: 133134) não se pode subestimar o decréscimo populacional provocado pela peste, mas este seria um fator secundário para explicar a desagregação do Império Romano, para ele primordialmente associada às invasões do século $\mathrm{V}$.

É importante notar que as discordâncias situam-se primordialmente na questão da escala e do peso relativo da peste nas transformações do mundo romano, ainda que subsistam questionamentos acerca da correta identificação das epidemias citadas nas fontes narrativas. ${ }^{5}$ Lee Mordechai e Merle Eisemberg (2019) têm insistido na necessidade de refinar simultaneamente as investigações nos campos da História, Arqueologia, Epidemiologia e Microbiologia. Eles sustentam sua visão minimalista da peste do século VI mediante a comparação das fontes narrativas com registros epigráficos, legislativos e arqueológicos organizados em séries temporais com intervalos curtos. Sua conclusão é que, embora os cronistas antigos falem numa mortalidade inaudita, os indícios das demais fontes não confirmam essa afirmação. Em seu levantamento são identificados relativamente poucos enterramentos compartilhando sepulturas, por exemplo, bem como não são detectados na legislação imperial sinais de enfrentamento de problemas associados à peste (Eisemberg; Mordecahi, 2019; Mordechai et al., 2019). Numa outra linha de investigação, Lauren White e Lee Mordechai (2020) estudaram o surto de 542 em Constantinopla mediante modelos matemáticos para a propagação de epidemias, concluindo que a duração, a mortalidade e a difusão aparecem superestimadas nas fontes narrativas (White; Mordechai, 2020: 16-17). 
Esses pontos de vista contrastantes refletem não apenas discordâncias teóricometodológicas, mas expressam também diferenças em termos de visões de mundo e da própria concepção de história. É a valorização das permanências frente às mudanças abruptas que opõe Durliat a Le Goff, Sarris, Allen ou Liebschultz. Por outro lado, a relação entre mudanças sociais e causas externas afasta Wickham das abordagens de Stathakopoulos e Harper. Para este último por exemplo, a queda do Império Romano demonstra a impossibilidade humana de controlar ou desafiar a natureza. A interconexão que caracterizava o mundo romano teria criado as condições para sua destruição (Harper, 2017). Wickham, por sua vez, fiel à perspectiva do materialismo histórico, vai buscar a centralidade dessa mudança nas estruturas sociais, embora não desconsidere a ação imediata das forças externas (Wickham, 2005).

De qualquer modo cabe lembrar que o Império Romano não desapareceu, embora tenha se desintegrado política e territorialmente no Ocidente. A parte oriental, porém, perdurou por mais de quinhentos anos depois da Peste Justiniana. Por outro lado, por menor que possam ter sido os impactos da peste bubônica enrte os séculos VI e VIII, é inegável que os que viveram essa experiência foram por ela profundamente marcados, não podendo sua voz ser simplesmente abafada pela análise fria dos fragmentos que o passado nos legou. Teriam eles e elas, homens e mulheres atingidos pelo flagelo da pandemia, captado para além da peste propriamente dita os sinais de um mundo em decomposição? Olhemos mais de perto a contribuição de um deles.

\section{A Gália de Gregório de Tours e suas doenças}

O bispo, hagiógrafo e cronista que conhecemos como Gregório de Tours ocupou a cátedra episcopal dessa cidade de 573 até sua morte, em 594. Nascido por volta de 538 em Clermont, na Auvérnia, Gregório provinha de um meio familiar com vínculos bastante estreitos com o clero da Gália. Sua parentela contava com vários bispos que atuaram em diferentes localidades, como a própria Clermont, Lyon, Langres e mesmo Tours, onde Gregório veio a suceder seu primo Eufrônio na função episcopal. Durante seu episcopado produziu uma extensa obra literária composta por coleções de milagres, vidas de santos, tratados litúrgicos e uma extensa narrativa historiográfica em dez livros. $^{6}$ 
Ao longo de toda a obra gregoriana são frequentes as referências a doenças e sua cura pelos poderes miraculosos atribuídos aos santos e suas relíquias. Isso se manifesta de modo especial nos textos de natureza hagiográfica, caso das coleções de milagres associados a São Martinho de Tours (De virtutibus sancti Martini episcopi - VM), São Juliano de Brioude (De passione et virtutibus sancti Iuliani martyris - VJ) e a diversos outros mártires e confessores (Liber in Gloria martyrum - GM, Liber in gloria confessorum - GC), bem como no conjunto de vidas de santos produzido por Gregório (Liber vitae patrum - VP). ${ }^{7}$ Isso evidentemente condiz com a natureza desse tipo de narrativa, visto as curas e exorcismos constituírem a principal matéria trabalhada na exaltação dos santos e consequente afirmação de seu culto. Mas na parte cronística da produção do bispo de Tours, as Historiae ou Decem libri historiarum (LH), figuram igualmente narrativas de curas miraculosas e outras referências a doenças que chamaram a atenção ou mesmo causaram impacto direto na vida do cronista. ${ }^{8}$ Dentre elas encontra-se a epidemia de peste bubônica sobre a qual temos discorrido neste trabalho.

Seguindo-se a ordem cronológica das Historiae, a primeira manifestação da peste na Gália aparece no relato de episódios ocorridos por volta de 542. Trata-se da narrativa dos esforços empreendidos pelo bispo Galo de Clermont $(† 551)$, tio paterno de Gregório, para a proteção espiritual de sua cidade, visto avizinhar-se uma epidemia identificada como lues inguinaria, a qual já devastava a cidade de Arles (LH 4,5). De acordo com esses relatos, um anjo anunciou a Galo que a cidade seria poupada durante oito anos, tempo que também restaria de vida ao bispo. Galo então instituiu as Rogações em Clermont, na forma de uma procissão que seguiria da cidade até o santuário de São Juliano, em Briuode, numa distância de cerca de $65 \mathrm{~km} .{ }^{9}$ Casas e igrejas teriam sido miraculosamente marcadas com um sinal semelhante a uma cruz, identificado por Gregório como a letra tau. O mesmo episódio é reproduzido no Liber vitae patrum, no capítulo dedicado à vida de Galo (VP 6,6), mas nesse caso não é feita menção ao sinal nas paredes. No Liber in gloria martyrum essa primeira ocorrência da peste na Gália é também recordada, registrando-se a suposta intervenção do mártir São Benigno em favor da mãe de Gregório e de sua família (GM 50).

Nessas menções à peste em Clermont em meados do século VI não há uma descrição de sintomas e nem referência à virulência da doença. Mas a identificação lues 
permite associá-la a uma moléstia que atinge de forma repentina e violenta a população, com a força de uma inundação. ${ }^{10}$ A adjetivação inguinaria, por sua vez, remete ao surgimento de tumores na região da virilha (inguina), o que é compatível com a peste bubônica (Gaffiot, 1934: 820).

Se examinarmos as ocorrências nas Historiae de termos como inguinaria ou inguen podemos mapear as demais referências à peste ou ao menos a moléstias a ela assemelhadas. A principal delas refere-se ao surto de 571 em Clermont (LH 4,31), passagem destacada por Biraben e Le Goff dentre as descrições mais detalhadas dos efeitos mortais da epidemia no Ocidente (Biraben; Le Goff, 1969: 1491). O relato de Gregório fala numa profusão de mortos, chegando a trezentos corpos num só dia na basílica de São Pedro e mais de dez cadáveres depositados na mesma sepultura. A morte era rápida, chegando cerca de três dias após o aparecimento de uma ferida, assemelhando-se a uma mordedura de serpente, na virilha ou na axila. A epidemia vitimou, entre outros, o bispo local, Cautinus, afligindo também as cidades de Lyon, Bourges, Chalon-sur-Saône e Dijon.

O surto de 571 também aparece nos textos hagiográficos do bispo de Tours. No livro dedicado aos milagres de São Juliano de Brioude (VJ 46a) ele serve como pano de fundo para criticar o recurso a práticas curativas associadas ao paganismo. Segundo Gregório, dois jovens escravos de sua família foram acometidos pela doença. Um deles morreu após ser tratado por curandeiros com encantamentos e ligaduras presas ao pescoço. O outro sobreviveu, tendo sido curado após beber água misturada à terra retirada das cercanias do túmulo de São Juliano. Nesse relato aparece a descrição de outros sintomas, como febre, dores abdominais e vômitos.

No Liber vitae patrum há também uma referência a um surto de peste bubônica na Auvérnia, provavelmente este de 571. ${ }^{11}$ Trata-se do enfrentamento entre o monge Pátroclo e uma mulher chamada Leubella, que dizia ter recebido do próprio São Martinho donativos que deveriam ser usados para curar o povo. Esses teriam desaparecido diante do monge, revelando-se assim sua origem diabólica (VP 9,2).

Também o livro dedicado aos mártires em geral registra uma procissão em Reims que teria protegido a cidade da peste. Os paramentos que cobriam a tumba de São Remígio, patrono local, percorreram à maneira de um cortejo fúnebre a cidade e aldeias 
próximas, o que teria contido a doença. Nesse caso, porém, a datação do episódio é incerta, podendo estar relacionado ao surtos de 543, 571 ou algum outro subsequente.

As referências nas Historiae de Gregório a doenças que se assemelham à peste bubônica são retomadas nas seções de sua obra que se seguem ao ano 580. A peste teria aparecido em Narbonne, entre 582 e 584 (inguinarius morbus- LH 6,14; morbi, lues 6,33), ${ }^{12}$ Albi, em 584 (morbi, lues - LH 6,33; inguinarius morbus - 7,1), Marselha, entre 588 e 591 (luae inguinaria - LH 9,21-22; morbus saepe nominatus - LH 10,25) e Roma, em 590 (cladis inguinaria - LH 10,1). Temos ainda algumas menções genéricas a graves epidemias que podem ter constituído manifestações da peste, como em Poitiers, por volta de 582 (gravis lues - LH 5,41), Arles, em 586 (gravis lues - LH 8,39) e na Itália, em 588 (gravissima lues - LH 9,20).

Boa parte desses episódios é precedida por eventos extraordinários tomados por Gregório como presságios: aparição de cometas, enchentes, acidentes com raios, comportamento estranho de animais e aspecto incomum dos astros. Mas registra-se também a percepção de que se tratava de um flagelo que agia mediante o contágio, embora não sejam fornecidas explicações para o mesmo. Gregório chega a mapear a trajetória da epidemia de 588 em Marselha. De acordo com sua narrativa a doença teria sido trazida da Espanha por um navio que descarregara mercadorias no porto local. Os que compraram parte da carga se contaminaram, chegando a ser registrada a morte de todas as oito pessoas que habitavam uma certa casa. A difusão da peste é comparada ao alastramento de um incêndio, castigando a cidade por dois meses, findos os quais deu-se um abrandamento dos contágios. Algum tempo depois a doença voltou a atacar, o que teria se repetido nos anos seguintes ( $\mathrm{LH} \mathrm{9,22).}$

As reações combinavam o apelo à clemência divina e a fuga dos lugares infectados. Gregório de Tours enaltece os que enfrentaram a doença e adotaram uma postura penitencial, como no caso do padre Cato, de Clermont, que em 571 recusou-se a deixar a cidade e continuou a celebrar missas e sepultar os mortos, até morrer vitimado pela praga (LH 4,31). Também teria sido esse o exemplo dado pelo rei o rei Gontrão (561-592), que em 588 ordenou a celebração de vigílias e jejuns em Marselha. Lá também o bispo local, Teodoro, teria se mantido ativo na condução de preces e vigílias, embora não residindo na residência episcopal, permanecendo refugiado na igreja de São Vítor (LH 9,22). Ação semelhante é atribuída ao papa Gregório Magno (590-604), que 
ainda diácono organizou procissões penitenciais em Roma durante o surto de peste que vitimou, entre outros, o seu predecessor, Pelágio II (579-590) (LH 10,1).

A fuga aparece no texto gregoriano como sinal de fraqueza, uma forma inútil de tentar escapar da punição divina. Por isso é criticado o bispo Cautinus, de Clermont, que percorreu em fuga diversas cidades, mas acabou retornando e morreu de peste numa Sexta-feira Santa (LH 4,31). ${ }^{13}$ Em Nantes muitos habitantes fugiram em 582 e se mantiveram ausentes por quase três anos. Alguns voltaram à cidade ainda em meio à ação da epidemia, acabando por morrer vitimados por ela (LH 6,33). O mesmo teria se dado com os habitantes de Marselha, em 588 (LH 9,22).

Tomando-se as prováveis referências à peste bubônica em conjunto, chegamos a quatro ciclos ou ondas da mesma na Gália: 543 (Arles, Clermont), 571 (Clermont, Lyon, Bourges, Chalon-sur-Saône, Dijon), 582-584 (Narbonne, Albi) e 588-591 (Marselha). Trata-se de uma persistência considerável no tempo e uma ampla dispersão no espaço. Entretanto os textos gregorianos não fornecem informações que permitam avaliações quantitativas, tampouco trazem descrições precisas dos sintomas e da evolução da doença, à exceção do surto de Clermont, em 571. Note-se ainda que as referências a essa doença na parte hagiográfica de sua obra são dispersas e trazem pouca informação adicional. Nesse particular chama a atenção a ausência de tais referências nos quatro livros dedicados aos milagres de São Martinho de Tours (De virtutibus sancti Martini episcopi), peça central do corpus hagiográfico gregoriano por tratar do culto do santo patrono de Tours. Nessa obra os relatos de milagres são organizados em sequência cronológica, num registro anual que acompanha a carreira episcopal do próprio Gregório. ${ }^{14}$ Em muitos dos relatos de curas são descritos os sintomas e as consequências das doenças, com destaque para casos de cegueira, paralisia, surdez e febres em geral. Mas a peste aí não aparece. ${ }^{15}$

Isso indica que a peste bubônica ocupava um lugar importante mas não central no panorama das doenças que afligiam a Gália nos século VI, ao menos na perspectiva de um observador agudo e relativamente bem informado como o bispo de Tours. É preciso considerar ainda que outras doenças receberam dele tratamento igual ou muito próximo ao reservado à peste. Nas Historiae, por exemplo, há uma detalhada e vívida narrativa de um surto de disenteria que em 580 vitimou dois filhos do rei franco Chilperico (561 584), a rainha Austrechildis, esposa de outro rei franco, Gontrão (561-592) e o conte 
Nantino, de Angoulême (LH 5,34-36). Do mesmo modo que a peste essa epidemia teria sido anunciada por presságios, como terremotos, inundações, luzes e sons estranhos. Identificada como morbus desentericus a doença também aparece como lues gravissima (LH 5,34), incluindo na sua sintomatologia, além da disenteria propriamente dita, vômitos, febre, dores na cabeça, pescoço e costas. Gregório afirma que muitos supunham tratar-se de algum veneno acrescentando que alguns doentes melhoravam após consumir ervas conhecidas como antídotos, enquanto outros recorriam a ventosas aplicadas às costas. Nesse último caso formava-se um tumor pustulento, a cura ocorrendo após a supuração do mesmo. A virulência da moléstia levou o bispo de Tours a redigir um pungente lamento acerca da morte de crianças em sua cidade, algumas das quais teriam sido cuidadas por ele próprio. Ao contrário da peste bubônica esse surto disentérico é mencionado também no De virtutibus sancti Martini, fazendo-se referência aos tumores e à cura obtida junto à tumba do santo (VM 2,51).

Outras moléstias também mereceram do bispo de Tours a qualificação de flagelo (lues), caso de uma doença que em 591 afetou Nantes e Tours, provocando a morte de várias pessoas, embora seu sintoma inicial fosse apenas uma leve dor de cabeça. A epidemia teria sido vencida após serem realizadas as Rogações, com jejuns e esmolas (LH 10,30). Uma outra doença associada a pústulas aparece nos textos gregorianos como dotada da força de um flagelo, (magna lues - LH 6,14). Seu primeiro registro associado ao ano 582, é bastante vago, pois Gregório apenas informa que provocou a morte de muitos, mas não precisa em que regiões. Não parece, porém, tratar-se da peste, pois no mesmo relato o bispo de Tours registra a ocorrência desta em Narbonne, mas fazendo a identificação precisa de morbus inguinarius (LH 6,14). Uma descrição mais detalhada aparece no De virtutibus sancti Martini, associada aos registros do ano 583, em Tours. Nesse caso Gregório fala em devastação, com os doentes sendo acometidos por febre e prostração, ao que se seguia o aparecimento de tumores e pequenas pústulas, brancos, duros e doloridos. Segundo o bispo nenhum remédio conhecido produzia efeito, sendo eficaz apenas a água com que era lavado o túmulo de São Martinho à época da Páscoa (VM 3,34). ${ }^{16}$

O que resulta desse quadro descritivo das moléstias classificadas por Gregório como flagelo é a sua vinculação estreita com o fluxo temporal da narrativa. Ao lermos as Historiae somos levados a acompanhar não apenas os conflitos políticos ou as 
querelas eclesiásticas nelas narrados, mas também a presença constante e ameaçadora de surtos epidêmicos que fugiam ao padrão das moléstias cotidianamente enfrentadas pelos homens e mulheres desse tempo. É preciso, porém, considerarmos o significado desses relatos na própria lógica que preside a composição da obra gregoriana.

As Historiae de Gregório se apresentam como uma narrativa iniciada com a criação do mundo e que se concentra progressivamente na Gália da época do autor, passando antes por eventos centrais na história sagrada vétero e neo-testamentária, especialmente as alianças celebradas entre Javé e o povo hebreu, a encarnação, morte e ressurreição de Cristo e a ação da Igreja nos tempos apostólicos. ${ }^{17} \mathrm{O}$ livro I encerra-se com a morte de São Martinho de Tours, tratado como apóstolo da Gália, definindo a concentração espacial da narrativa desse ponto em diante nessa região. Os livros seguintes prosseguem nesse duplo afunilamento, temporal e espacial, de modo que do $\mathrm{V}$ ao $\mathrm{X}$ a narrativa cobre pouco mais de vinte anos, o que corresponde à época vivida pelo próprio autor. Tratava-se para Gregório de contar a história de seu tempo e de seu mundo, mas numa perspectiva que buscava destacar a coexistência entre pecado e virtude, felicidade e tragédia. Ele próprio assim o define, ao afirmar que procurava recordar de maneira entremeada os milagres operados pelos santos e as desgraças que afligiam os povos ("[...] mixte confusequae tam virtutes sanctorum quam strages gentium memoramus" - LH 2, prólogo).

Como observa Martin Heinzelmann (2001) não se pode perder de vista a dimensão escatológica da obra. Para Gregório o mundo caminhava para um fim próximo. Assim como o livro I incia-se com a criação do mundo, o livro X aponta para o fim dos tempos. Não por acaso fomes, terremotos, doenças e outros sinais associados aos discursos de Cristo sobre o Juízo Final nos evangelhos aí são evocados. Uma das referências à peste bubônica que listamos acima aparece justamente na abertura desse livro (Marselha - 591), colocada ao lado do registro de uma grande fome que atingiu Angers, Nantes e Le Mans. Segue-se a recordação das palavras de Cristo sobre sinais do fim dos tempos, evocando peste, fome, terremoto e manifestação de falsos profetas, passando-se em seguida à narrativa da história de um homem que se dizia Cristo e provocou revoltas e saques em várias cidades da Gália (LH 1,25). Isso nos serve de alerta para tomar as referências de Gregório à peste e outras doenças não apenas na sua 
dimensão factual, mas compreendê-las como peças da construção de um conjunto narrativo que buscava explicar e dar sentido à história.

Uma segunda proposição de Heinzelmann (2001) acerca do plano narrativo das Historiae será aqui de grande utilidade: a ideia do fluxo dos acontecimentos influenciado pela ação do pecado. Para Gregório a Igreja, enquanto comunidade de fieis, atravessava o mundo como a arca de Noé nos tempos do dilúvio, acossada pelas vagas das desgraças produzidas pela ação dos que sucumbiam ao pecado. Seria papel das lideranças eclesiásticas e dos reis garantir que a ordem cristã prevalecesse. $\mathrm{Ou}$, em outras palavras, edificar a Igreja (ecclesiae aedificatio). Quando eles falhavam o pecado triunfava e a ira divina se abatia sobre homens e mulheres. Por isso o relato de desgraças, especialmente as guerras que opunham entre si os reis francos que no século VI disputavam a arena política na Gália, costuma ser precedido no texto gregoriano por expressões que remetem à ação do pecado (peccatis facientibus - LH 4,23; 4,47; 4,51; 7,33) ou ao agravamento do mesmo (peccatis increscentibus - LH 6,3; peccatis ingruentibus - LH 5,48). Numa lógica significativamente semelhante a epidemia de disenteria de 580 é associada à discórdia entre os reis: "Sed haec prodigia gravissima lues est subsecuta. Nam et discordantibus reges et iterum bellum civile parantibus, desentericus morbus paene Gallias totas praeoccupavit" (LH 5,34). ${ }^{18}$

Desse modo no texto gregoriano as doenças não apenas têm história, para parafrasear Le Goff (1991), mas são elas próprias matéria e motor da história. A peste, por mais letal que tenha sido, não parece ter produzido no autor um impacto para além daquele experimentado diante de outras calamidades. Isso sugere, por um lado, a resiliência da sociedade diante das ocorrências pestíferas. Os surtos vêm e vão e a vida segue, conclusão que parece corroborar a visão minimalista acerca dos efeitos marginais da peste no século VI. Mas, por outro lado, mais do que o impacto de uma ou várias ondas dessa moléstia, as narrativas gregorianas evidenciam um estado de enraizamento no cotidiano da ocorrência de epidemias diversas. Gregório nos revela sua percepção dessa condição no plano espiritual, mas seu retrato de um mundo doente por causa do pecado nos permite vislumbrar uma sociedade fisicamente doente e materialmente empobrecida. A Peste Justiniana, mais do que a causa de uma crise, merece ser tratada como um episódio revelador de uma decomposição mais profunda da ordem social, 
como um facho de luz que nos permite enxergar numa zona mal iluminada pela documentação histórica.

É importante não perder de vista que olhamos a peste no século VI e seus desdobramentos sob a perspectiva do nosso tempo, envoltos nas incertezas das mudanças climáticas e ameaçados pelas ondas mortíferas de uma pandemia. Nosso modo de vida conectado e globalizado nos expõe à propagação incontrolável de doenças, enquanto permanecemos impotentes diante da tragédia da fome e da miséria que nossas conquistas científicas não conseguem vencer. Não é por acaso que a associação entre ação da natureza e modo de vida são evocados para explicar o fim de uma era (Harper, 2017). E é sintomático que pouco antes de mergulharmos no caos da pandemia da Covid19 houvesse tantos debates acerca da dimensão e dos efeitos de uma outra pandemia, que se não foi a causa do fim ao menos consistiu no sinal de que uma era findava. O futuro dirá se não estamos também a contemplar e a viver o fim deste nosso mundo.

\section{Referências}

Fontes primárias:

EVAGRIUS SCHOLASTICUS. The Ecclesiastical History of Evagrius Scholasticus. Ed. Michael Withby. Liverpool: Liverpool, University Press, 2000. [Trasnlated Text for Historians, v. 23 = Evágrio, História Eclesiástica].

GREGORIUS TURONENSIS. Historiarum libri X. Monumenta Germaniae Historica (MGH), Scriptores Rerum Merovingicarum (SRM), t.1.1, ed. alt. Bruno Krusch et W. Levison. Hannover, 1951. [Disponível também a partir de

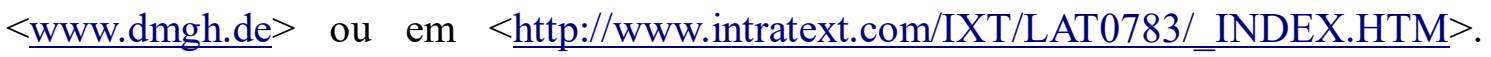
Acesso 30jan. 2021].

Miracula et opera minora. MGH, SRM t.1.2, ed. Bruno Krsch, Hannover, 1969. [Disponível também a partir de <www.dmgh.de $>$ ou em $<$ http://profs.lettere.univr.it/labium/GDTAIPER/testi.htm $>$ - Projeto "Gregorio di Tours Agiografo", a cura di Antonio di Prisco (Università di Verona). Acesso 30jan. 2021]. 
Libri miraculorum alique opera minora. Ed. H. Bordier. Paris : Societé de l'Histoire de France, 1857-1864. 4.t.

GRÉGOIRE DE TOURS. Histoire des Francs. Trad. Robert Latouche. Paris: Les Belles-Lettres, 1999. 2t.

GREGORY OF TOURS. Glory of the confessors. Trad. Raymond Van Dam. Liverpool: Liverpool University Press, 1988.

Glory of the martyrs. Trad. Raymond Van Dam. Liverpool: Liverpool University Press, 1988.

. Life of the fathers. 2. ed. Trad. Edward James. Liverpool: Liverpool University Press, 1996.

. The miracles of the Bishop St. Martin. In: VAN DAM, Raymond. Saints and their miracles in Late Antique Gaul. Princeton: Princeton University Press, 1993, p. 199-303.

GREGORY OF TOURS. The suffering and miracles of the Martyr St. Julian. In: VAN DAM, Raymond. Saints and their miracles in Late Antique Gaul. Princeton: Princeton University Press, 1993, p. 162-198.

PROCOPIUS. History of the wars. Ed. H. B. Dewing. London: William Heinemann, 1914, v.1 [= Procópio, Guerras Persas].

Referências gerais:

ALLEN, P. The "Justinianic” Plague. Byzantion, v. 49, p.5-20, 1979.

BIRABEN, J.-N.; LE GOFF, Jacques. La peste dans le Haut Moyen Âge. Annales. Histoire, Sciences sociales, v.24, n.6, 1969, p.1484-1510.

BIRABEN, J.-N. Les hommes et la peste en France et dans les pays européens et méditerranéens. 2.v. Paris: La Haye, 1975.

. Les maladies en Europe : équilibres et ruptures de la pathocénose. In : GRMEK, Mirko (Dir.). Histoire de la pensée médicale en Occident I : Antiquité et Moyen Âge. Paris : Éditions du Seuil, 1995, p.283-310. 
BRAMANTI, B. et al. A critical review of anthropological studies on skeletons from European plague pits of diferent epochs. Scientific reports, v. 8, n. 1, p. 17655, 5 Dec. 2018.

DRANCOURT, Michel et al. Yersinia pestis Orientalis in remains of ancient plague patients. Emerging infectiuos diseases. v. 13, n. 2, 2007.

DURLIAT, Jean. La Peste du VIe siècle : pour un nouvel examen des sources byzantines. In : ABADIE-RENAL, Catherine. (Org.). Hommes et richesses dans l'Empire Byzantin. t. 1. Paris : P. Lethielleux, 1989, p.107-119.

EISEMBERG, Merle ; MORDECHAI, Lee. The Justinianic Plague: an interdisciplinary review. Byzantine and Modern Greek Studies. v. 43, n. 2, p. 156$180,2019$.

EWIG, Eugen. Le culte de saint Martin à l'époque franque. In: Revue d'histoire de l'Église de France, t. 47, n.144, p. 1-18, 1961.

FREITAS, Edmar Checon de. Gregório de Tours e a sociedade cristã na Gália dos séculos V-VI. Niterói: Eduff, 2015.

GAFFIOT, Félix. Dictionaire Latin - Français. Paris: Hachette, 1934.

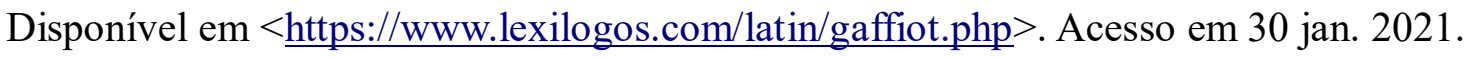

GEARY, Patrick J. Before France and Germany : the creation and transformation of the Merovingian world. New York: Oxford University Press, 1988.

GILBERT, M. et al. Absence of Yersinia pestis-specific DNA in human teeth from five European excavations of putative plague victims. Microbiology, v. 150, p. 341-35, 2004.

GOFFART, Walter. The narrators of Barbarian history: Jordanes, Gregory of Tours, Bede and Paul the Deacon. 2.ed. Notre Dame: University of Notre Dame Press, 2005.

HARBECK, Michaela et al. Yersinia pestis DNA from skeletal remains from the 6th Century AD reveals insights into Justinianic Plague. PLOS pathogens, v. 9, n. 5, maio 2013.

HARPER, Kyle. The fate of Rome : climate, disease and the end of Empire. Princeton : Princeton University Press, 2017. 
HEINZELMANN, Martin. Gregory of Tours : history and society in the sixth century. Tradução de Christopher Carroll. Cambridge: University of Cambridge Press, 2001 .

Une source de base de la littérature hagiographique latine: les réceuils de miracles. In: HAGIOGRAPHIE, culture et societé - Ive-XIIe siècles. Actes du colloque organisé à Nanterre et à Paris (2-5 mai 1979). Paris: ètudes Augustiniennes, 1981, p. 235-259.

LECLERCQ, Henri. Rogations. In : MARROU, Henri (Dir.). Dictionaire d'Archeologie Chrétienne et de Liturgie. Paris: Letouzey et Ané, 1948. v. 2, p. 24592461 .

LE GOFF, Jacques (Org.). As doenças têm história. Lisboa : Terramar, 1991.

LE GOFF, Jacques; TRUONG, Nicolas. Uma história do corpo na Idade Média. Rio de Janeiro : Civilização Brasileira, 2006.

LIEBSCHUltZ, J. H. G. W. Decline and fall of Roman City. Oxford: Oxford University Press, 2001.

LITTLE, Lester (Ed.). Plague and the end of Antiquity: the pandemic of 541750. Cambridge: Cambridge University Press, 2006.

MITCHELL, Kathleen; WOOD, Ian (Org.). The world of Gregory of Tours. Leiden : Brill, 2002.

MORDECHAI, Lee; EISEMBERG, Merle. Rejecting catastrophe: the case of Justinianic Plague. Past and Present, n. 244, n.1, p. 3-50, ago. 2019.

MORDECHAI, Lee et al. The Justinianic Plague: An inconsequential pandemic? PNAS, v.116, n. 51, p.25546-25554, 17 Dec. 2019.

MURRAY, Alexander Callander (Ed.). A companion to Gregory of Tours. Boston: Brill, 2015.

PESSOA, Tomás de Almeida. Materialidade e poder: a família de Gregório de Tours e o culto de São Martinho (sécs. V e VI). 2019. Dissertação (Mestrado em História) - Programa de Pós-Graduação em História. Universidade Federal Fluminense. Niterói. 
PIETRI, Luce. La ville de Tours du IVe au VIe siècle : naissance d'une cité chrétienne. Rome : École Française de Rome, 1983.

. Le pélerinage martinien de Tours à l'époque de l'évêque Grégoire. In : CONVEGNI DEL CENTRO DI STUDI SULLA SPIRITUALITÀ MEDIEVALE, 12. 1971, Todi. Gregorio di Tours. Todi: Accademia Tudertina, 1977, p.93-139.

ROSEN, William. Justinian's flea: plague, empire and the birth of Europe. London: Viking, 2007.

RUSSEL, Josiah C. That earlier plague. Demography 5(1), 1968, p.174-184.

SALLARES, Robert. Ecology, evolution, and epidemiology of plague. In: LITTLE, Lester (Ed.). Plague and the end of Antiquity: the pandemic of 541-750. Cambridge: Cambridge University Press, 2006, p.231-289.

SARRIS, Peter. The Justinianic plague: origins and effects. Continuity and change, n. 17, p.169-182, 2002.

SCHMITT, Jean-Claude. Le séminaire. In: REVEL, Jacques; SCHMITT, JeanClaude (Org.). L'ogre historien: autour de Jacques Le Goff. Paris: Gallimard, 1998, p.17-32.

SHANZER, Danuta; WOOD, Ian. Avitus of Vienne : letters and selected prose. Liverpool : Liverpool University Press, 2002. [Translated Texts for Historians, v. 38].

STATHAKOPOULOS, Dionysios. Famine and pestilence in the Late Roman and Early Byzantine Empire : a systematic survey of subsistence crises and epidemics. Surrey : Ashgate, 2004 ; London: Routledge, 2016.

VAN DAM, Raymond. Leadership and community in Late Antique Gaul. Berkely: University of California Press, 1992.

. Saints and their miracles in Late Antique Gaul. Princeton: Princeton University Press, 1993.

WAGNER, David et al. Yersinia pestis and the Plague of Justinian 541-543 AD: a genomic analysis. The Lancet: infectious disease, v.14, p. 319-326, abr. 2014.

WARD-PERKINS, Bryan. The fall of Rome and the end of civilization. Oxford : Oxford University Press, 2005. 
WHITE, Lauren; MORDECHAI, Lee. Modeling the Justinianic Plague: Comparing hypothesized transmission routes. PLOS one, v. 15, n. 4, p. 1-21. 30 Apr. 2020. Disponível em $<$ https://doi.org/10.1371/journal.pone.023125>. Acesso em 30 out. 2020 .

WICKHAM, Chris. Framing the Early Middle Ages: Europe and Mediterranean - 400-800. Oxford : Oxford University Press, 2005.

The inheritance of Rome: a history of Europe from 400 to 1000. London : Penguin, 2009. [Tradução brasileira : O legado de Roma : iluminando a idade das trevas, 400-1000. Campinas : Unicamp, 2019].

WIECHMANN, Ingrid ; GRUPE, Gisela. Detection of Yersinia pestis DNA in two early medieval skeletal finds from Ascheim (Upper Bavaria, 6th Century A.D.). American Journal of Physical Anthropology, n. 126, p.48-55, 2005.

WOOD, Ian. The Merovingian kingdoms. London: Longman, 1994.

\section{Notas}

\footnotetext{
${ }^{1}$ No ano anterior um artigo de Josiah C. Russel (1968) já abordara o tema na revista Demography. Le Goff registra as interessantes hipóteses formuladas no mesmo, ao mesmo tempo em que critica sua fraqueza metodológica (Le Goff; Biraben, 1969: 1492, n.1).

${ }^{2}$ Para as publicações anteriores de J.-N. Biraben sobre o tema veja-se a seção "Orientattion bibliographique” em Biraben; Le Goff, 1969: 1508. As conclusões de J.-N. Biraben foram integradas posteriormente na sua obra Les hommes et la peste en France et dans les pays europeens et mediteraneens (Biraben, 1975), tendo o autor também voltado ao tema em outros trabalhos (Biraben, 1989; 1995). Quanto a Le Goff, a relação entre o estudo das doenças e os universos cultural e social em que se inseriam voltou a se manifestar em seus trabalhos vinculados ao campo da Antropologia Histórica, caso de Les maladies ont une histoire (1985) e Une histoire du corps au Moyen Âge (2003); cf. Le Goff, 1991; Le Goff; Truong, 2006.

${ }^{3}$ Essa identificação do $Y$. pestis em restos humanos antigos foi objeto de crítica entre alguns especialistas, que apontaram falhas nos protocolos contra contaminação. Embora estudos consecutivos tenham cobfirmado essa identificação subsistem dúvidas quanto à correlação precisa entre os dados que envolvem DNA e os achados arqueológicos em geral. Isso porque o número de ocorrências positivas para o $Y$. pestis é pequeno quando comparado ao conjunto humano representado pelos enterramentos. Para uma discussão mais ampla vejam-se Eisemberg; Mordechai, 2019; Bramanti et al., 2018.

${ }^{4} \mathrm{~A}$ importância da relação entre o Y. pestis e o Y. pseudotuberculosis já havia sido sugerida no artigo de Biraben e Le Goff, que discutem com ceticismo a hipótese de uma ação imunizante do segundo que ajudaria a explicar o fim das grandes epidemias de peste (Biraben; Le Goff, 1969: 1490-1491).

${ }^{5}$ Cf. comentários sobre esse ponto em Harbeck et al., 2013 e Sallares, 2007.

${ }^{6}$ Sobre a vida e a obra de Gregório de Tours vejam-se, especialmente: Van Dam (1993), Heizelmann (2004) e Goffart (2005); e para o contexto geral da sua época: Wood (1994), Geary (1988), Mitchel; Wood (2002), Murray (2015).

${ }^{7}$ A produção hagiográfica de Gregório de Tours e o tratado litúrgico De cursu stelarum ratio encontramse em Monumenta Germaniae Historica (MGH), Scriptores Rerum Merovingicarum (SRM) 1.2. Disponível em 〈https://www.dmgh.de/mgh_ss rer_merov 1_2/index.htm>.
} 
${ }^{8}$ As Historiae, geralmente identificadas de modo equivocado como História dos Francos, encontram-se em MGH, SRM, 1.1. Disponível em <https://www.dmgh.de/mgh_ss_rer_merov_1_1/index.htm>.

${ }^{9}$ As Rogações eram procissões penitenciais, geralmente realizadas nos três dias que antecediam o domingo da Ascensão. Sua fixação na liturgia e difusão são atribuídas tradicionalmente ao bispo Mamerto de Vienne, por volta de 470. São conhecidas também como Pequenas Rogações, Litanias Menores ou Galicanas, como forma de diferenciá-la das Grandes Rogações (ou Litanias Maiores), instituídas em Roma pelo papa Gregório Magno, em 590. Cf. Leclercq, 1948; Shanzer; Wood, 2002: 381.

${ }^{10}$ Esse é com efeito o sentido primário de lues: algo líquido, como chuva ou neve; por extensão epidemia ou peste. Cf. Gaffiot, 1934: 926.

${ }^{11}$ Cf. nota de E. James em VP 9,2 (1991: 68, n.9).

${ }^{12}$ Em LH 6,15 Gregório de Tours informa que o bispo Felix de Nantes foi vitimado pela peste (582).

${ }^{13}$ Gregório de Tours não tinha em boa conta o bispo Cautinus, a quem acusa de crueldade e cupidez (LH 4, 5-7; Van Dam, 1993: 58-60).

${ }^{14} \mathrm{Na}$ verdade Gregório se apresenta como devoto especial de São Martinho tempos antes de se tronar bispo, justamente ao ser curado de uma grave moléstia junto à tumba do santo, em 563 (VM 1,32; Van Dam, 1993: 55). Ao longo dos quatro livros que compõem o De virtutibus sancti Martini Gregório relata diversas curas das quais teria se beneficiado, marcando etapas da sua trajetória episcopal. Cf. Van Dam, 1993: 91-92.

${ }^{15}$ Sobre o culto de São Martinho em Tours vejam-se: Ewig, 1961; Pietri, 1977; 1983; Heinzelmann, 1981; Vam Dam, 1993; Freitas, 2015; Pessoa, 2019.

${ }^{16}$ Raymond Van Dam (1993: 273, n.86) identifica essa doença com a peste, conectando os episódios narrados em VM 3,34 com os de LH 6,14-15 e 6,33. Mas a nosso ver, tratava-se de duas moléstias diferentes. De fato LH 6,14 menciona ambas, mas para a epidemia de Narbonne usa a identificação inguinarius morbus. Mas ao falar em LH 6,33 numa doença que grassava em Narbonne "já há três anos" (iam tertio anno) estava se referindo de fato à peste bubônica.

${ }^{17}$ Sobre a composição, estrutura narrativa e propósitos das Historiae de Gregório de Tours vejam-se: Goffart, 1988; Heinzelmann, 2001; Freitas, 2015.

18“"Mas após esses prodígios seguiu-se uma epidemia. Com efeito, com os reis novamente em discórdia outra vez preparando uma guerra civil, a doença disentérica assolou quase toda a Gália" [Tradução nossa]. 